\title{
Solidariedade e expressão jurídica: valores políticos de vereadores sobre direitos sociais
}

\author{
Samira Kauchakje \\ Curso de Ciências Sociais e \\ Programa de Pós-Graduação em Gestão Urbana \\ Pontifícia Universidade Católica do Paraná
}

\begin{abstract}
Resumo: $\mathrm{O}$ artigo discute cultura política sobre direitos sociais e solidariedade, com base na pesquisa sobre valores políticos de parlamentares municipais de Curitiba. Considerou-se os direitos à saúde, educação, assistência social, trabalho, previdência social, segurança alimentar e nutricional, habitação e transferência de renda. A estratégia metodológica para identificar e interpretar valores foi: entrevista, sistematização e discussão focada em frequência e testes estatísticos e, também, análise a partir dos parâmetros da Constituição Federal de 1988 e de tipos ideais de solidariedade. Para o campo dos direitos sociais, foram elaborados os seguintes tipos de solidariedade: civil-pública; cívica-protetiva; pessoalista, benevolente; internacional e cosmopolita. Os resultados indicam que o legislativo municipal caracteriza-se por um perfil ideológico liberal e conservador e que os valores dos vereadores sofrem variação a depender da área de cada um dos direitos sociais. De forma geral, quanto se trata de transferência de renda e, em menor medida, de assistência social, os valores dos vereadores são compatíveis com a solidariedade cívica-protetiva ou beneficente; para a educação e saúde, os valores são congruentes com a solidariedade civilpública, isto é, com maior adesão aos atuais preceitos constitucionais e de cidadania.
\end{abstract}

Palavras-chave: valores políticos; direitos sociais; política social; solidariedade; legislativo municipal

Abstract: This article discusses values of city councilors of Curitiba-Brazil on social rights, such as: health, education, welfare, labor, social security, food security and nutrition, housing and income transfers. The methodological procedures include interviews, statistical tests and analysis from the parameters of the Constitution of 1988 and from types of solidarity. The types were divided in two groups: political solidarity and gift solidarity. The results indicate that for the case of the rights to the direct monetary transfer and social assistance, the values of city councilors are compatible to the characteristics of the gift solidarity. In the cases of education and health, the values are compatible to the constitutional principles and the political solidarity.

Keywords: political culture; social rights; social policy; solidarity; city councilors 
OPINIÃO PÚBLICA, Campinas, vol. 18, n², novembro, 2012, p. 309-336

\section{Introdução ${ }^{1}$}

Os direitos sociais (tais como assistência social, saúde, educação, segurança alimentar e nutricional, moradia, previdência social e trabalho) estão entre os direitos fundamentais na Constituição brasileira de 1988 (CF88), junto a outros anteriormente consagrados e aceitos culturalmente, como é o caso do direto à vida e à liberdade. Desta forma, têm a condição de cláusula pétrea e caráter inadiável para efetivação, abrindo-se assim a discussão sobre a judiciailização dos direitos sociais (PIOVESAN, VIEIRA, 2006).

A efetivação dos direitos sociais, entretanto, não se esgota nas instituições, passando, também, por seu reconhecimento e por uma cultura democrática. Autores como Sales (1994), Telles (2000), Reis (2000), Chauí (1994), Carvalho (2001) e Moisés (2005), por exemplo, indicam que não é este o traço da cultura política brasileira, a qual seria saturada pela noção da dádiva e de outorga pelos "poderosos" e pelo Estado. Esta disparidade entre instituições e cultura política parece modelar a concretização de mudanças institucionais e também as alterações dos valores, lembrando a discussão de Putnam para o caso da Itália (2000). Especialmente no âmbito municipal, parece que a elite política brasileira logrou articular o constrangimento da ordem legal e institucional à cultura da benesse e do favor (LOPEZ, 2004).

$\mathrm{Na}$ esfera municipal, os parlamentares agem por meio de moções, requerimentos e projetos de leis ${ }^{2}$ pautados pela legislação que rege as competências reduzidas do município no âmbito das políticas e direitos sociais e, não raro, realizam alguma espécie de atendimento social. Sua conduta expressa nas proposições legislativas ou na relação direta com setores da população é orientada por valores que, se partilhados e coerentes com aquela cultura política, podem reforçar o sentido de benesse no lugar de direitos.

Os municípios têm competências residuais para legislar sobre matéria social, mas, a despeito disso, são importantes no campo dos direitos sociais, seja porque estão presentes em atividades próprias ou concorrentes com outros entes federados ${ }^{3}$ (SoUZA, 2004) (Quadro 1), seja porque alguns parlamentares municipais utilizam requerimentos/indicações e atendimento social direito à população para "ampliar" seu raio de ação na área dos direitos sociais, articulando direitos e benesses; função pública e conexão eleitoral ${ }^{4}$.

\footnotetext{
1 Agradeço às sugestões do parecerista anônimo que permitiram o aperfeiçoamento do artigo.

2 As proposições legislativas podem ser agrupadas em: 1. Projetos de Lei e Emendas. 2. Indicações, Requerimentos e Solicitações. 3. Homenagens e Moções. Além dessas atividades, a maioria dos vereadores realiza atendimento social aos eleitores. Este visa satisfazer demandas que "são, na grande maioria das vezes, de caráter pessoal ou particularista". Indicações são os meios pelos quais os vereadores "fazem o encaminhamento formal de suas solicitações ao Executivo, justificadas como medidas de interesse público" que, não raro, está ligado à demanda de pessoas de sua efetiva ou potencial base eleitoral. Moção "é uma proposição encaminhada ao plenário com o objetivo de exaltar as realizações e qualidades de determinada pessoa ou instituição, ou mesmo uma data comemorativa" (LOPEZ, 2004, p. 156, 158 e 164).

${ }^{3}$ A maior parte das áreas da política social, como educação, saúde, assistência social, está orientada por um sistema único de desenho nacional descentralizado (ARRETCHE, 2000; DRAIBE, 1997; SOUZA, 2004).

${ }^{4}$ Conexão eleitoral se refere à "tradição que nasce com Downs (1957), que dá extrema importância nos processos eleitorais para as ações dos políticos, transformando-as em fator modulador das ações parlamentares (...). Assim, a atuação dos políticos no poder Legislativo é uma consequência funcional da necessidade de obter votos em futuras eleições.” (CERvı, 2009, p. 159). Esta argumentação é contestada pelo "modelo partidário", que entende que o comportamento dos parlamentares seria determinado pelos aspectos de organização interna, sistema de regras e importância dos líderes dos partidos. (CODATO, 2009, p. 1)
} 
KAUCHAKJE, S. Solidariedade e expressão jurídica: valores políticos de vereadores...

\section{Quadro 1 \\ Competências concorrentes e competências municipais}

\begin{tabular}{|c|c|}
\hline Esfera de governo & Serviços / Atividades (exemplos) \\
\hline Federal- estadual - local (competências partilhadas) & $\begin{array}{l}\text { Saúde, educação e assistência social pública } \\
\text { Habitação, saneamento e segurança no trânsito } \\
\text { Cultura e ciência } \\
\text { Preservação do patrimônio histórico, artístico e cultural } \\
\text { Agricultura e abastecimento familiar (segurança alimentar } \\
\text { e nutricional) } \\
\text { Combate à pobreza } \\
\text { Turismo e lazer } \\
\text { Política para pequenas empresas } \\
\text { Proteção do meio ambiente e dos recursos naturais } \\
\text { Preservação da floresta, da fauna e flora } \\
\text { Exploração das atividades hídricas e minerais }\end{array}$ \\
\hline Predominantemente local & $\begin{array}{l}\text { Pré-escola e educação fundamental } \\
\text { Saúde (unidades básicas e municipais) } \\
\text { Preservação histórica e cultural }\end{array}$ \\
\hline Apenas local & $\begin{array}{l}\text { Transporte coletivo } \\
\text { Uso do solo }\end{array}$ \\
\hline
\end{tabular}

Fonte: adaptado de Souza (2004).

Este artigo apresenta resultados da pesquisa que trata da compatibilidade dos valores dos vereadores de Curitiba sobre direitos sociais com as concepções da CF88 e de solidariedade ${ }^{5}$. Como parâmetro para a análise, foi elaborada uma tipologia de solidariedade baseada em elementos da cidadania no Brasil (CARVALHO, 2001), cuja história evidencia uma espécie de disputa entre, por um lado, a cultura da dádiva e, por outro, a expressão jurídica dos direitos sociais de acordo com a CF886

Aspectos históricos e da legislação são objeto da próxima seção do artigo; item do artigo, em seguida, há uma síntese sobre os procedimentos metodológicos e dos tipos de solidariedade e, por fim, são discutidos os primeiros achados quanto aos valores políticos dos vereadores sobre direitos sociais em relação às noções de solidariedade e princípios constitucionais ${ }^{7}$.

\footnotetext{
${ }^{5}$ Pesquisa apoiada pelo CNPq. Versões preliminares deste artigo foram apresentadas no VII Encontro da ABCP - Associação Brasileira de Ciência Política e no II Seminário Nacional de Sociologia e Política, UFPR.

${ }^{6}$ Comparato (2001, p. 10) entende que os direitos sociais são "expressões do princípio fundamental da solidariedade", conforme 0 art. $3^{\circ}$ sobre um dos objetivos fundamentais da República Federativa do Brasil: construir uma sociedade livre, justa e solidária. ${ }^{7}$ Foi encaminhada para outra publicação uma versão modificada do texto que apresenta discussão dos resultados com ênfase no perfil ideológico e partidário e na dicotomia esquerda e direita.
} 
OPINIÃO PÚBLICA, Campinas, vol. 18, n², novembro, 2012, p. 309-336

\section{Dimensão social dos direitos humanos}

Desde pelo menos o século XVIII, na maioria das sociedades ocidentais capitalistas (e também, em outras comunidades políticas, seja por conta das relações de poder, trocas culturais ou dinâmicas endógenas), as dimensões civis, políticas e socioeconômicas dos direitos têm sido objeto de medidas legais e de políticas públicas estatais e, também, de declarações e pactos entre países membros de organizações internacionais.

Marshall (1967) pontua que os direitos civis referem-se às liberdades individuais e econômicas; os políticos à participação no exercício do poder político; os sociais dizem respeito à participação na riqueza de acordo com o patrimônio e padrões culturais e materiais admitidos numa comunidade política. Há, ainda, as últimas gerações de direitos, relativos ao meio ambiente, à diversidade cultural e identitárias (por exemplo Bobbio, 1992; Arretche, 1995).

A cronologia marshalliana dos direitos é criticada por trazer etapas sequenciais do alargamento da cidadania baseada na experiência inglesa, sugerindo um mesmo padrão cumulativo em diferentes sociedades. Todavia, a especificação dos direitos empreendida pelo autor, articulada à base histórica, elucida seu conteúdo e alcance.

Em termos gerais, o marco histórico dos direitos civis é o século XVIII, mais propriamente a revolução política e econômica que configura a sociedade burguesa e consolida valores liberais. Tais direitos são de corte individual: a vida e as liberdades de propriedade, econômica, de expressão e pensamento, de associação, de ir e vir e de religião, especialmente. Os direitos políticos, consagrados a partir do século XIX, referem-se à formação e à associação em partidos e à participação política.

Os direitos sociais foram afirmados no final do século XIX e primeira metade do século XX a partir de movimentos e atores em colisão, tais como: as lutas de trabalhadores que viam os direitos socioeconômicos como conquista socialista e introdução de mecanismos de regulação no capitalismo; solidarista de inspiração humanitária; setores próximos ao liberalismo que os defendiam como medida de integração social e inclusão de trabalhadores no mercado de trabalho e no consumo; e críticos de esquerda que os entendiam como meios de socialização dos custos da reprodução social dos trabalhadores. De todo modo, as experiências do período entre as duas grandes guerras mundiais e o posterior crescimento econômico e de postos de emprego na primeira metade do século XX fomentaram a ampliação dos direitos sociais. O núcleo inicial dos direitos sociais, por sinal, girou em torno do mundo e condições do trabalho, ou seja: saúde, assistência e previdência social, ampliado para habitação e educação (DRAIBE, 1989; BeHRING, BoschetTI, 2007). Atualmente, são considerados como direitos sociais: educação, saúde, habitação, assistência social, previdência social, trabalho e segurança alimentar e nutricional. Algumas interpretações e legislações consideram, também, lazer, cultura, transporte e segurança pública ${ }^{8}$.

\footnotetext{
8 O processo de expansão de direitos e políticas sociais que edificou diferentes tipos de Estado de Bem Estar Social (EspinG. ANDERSEN, 1991) foi alterado pela onda neoliberalizante das últimas décadas do século XX. Nos dias de hoje, esta onda foi arrefecida. As explicações teóricas para isso ressaltam fatores como o aprofundamento da questão social; a mudança no padrão institucional internacional sobre política social; ou a força da trajetória das próprias instituições e políticas de bem estar social em cada Estado. Inclino-me para a terceira vertente explicativa e concordo que "inovações, correções e inflexões" afetaram
} 312 
KAUCHAKJE, S. Solidariedade e expressão jurídica: valores políticos de vereadores...

Na segunda metade do século XX, movimentos sociais de apelo mais cultural do que classista (OFFE, 1993; SCHERE-WARREN, 2006) inseriram na agenda pública os chamados direitos de últimas gerações relacionados ao gênero, livre orientação sexual, diversidade cultural e étnica, ciclo de vida, ambiente, desenvolvimento, entre outras temáticas.

Este processo histórico, mesmo que não repetido linearmente em diversas sociedades, rebate em suas configurações históricas particulares porque são processos que dão conta da "obra destrutiva da construção das sociedades modernas" e que "operaram sobre a ruína e a desagregação social de formas arraigadas de pertença e filiação comunitária." Isto é, "o processo simultâneo de ampliação do desarraigo, e de subordinação disciplinar da população aos ditames do mercado de trabalho, veio acompanhado de novas vias de integração" e por "mecanismos públicos de produção de legitimidade" os direitos de cidadania (LAVALLE, 2003, p. 74).

Com esta base de construção da cidadania moderna, não há, todavia, uma linearidade de desenvolvimento ou evolução previsível e nem homogeneidade entre as comunidades políticas nacionais ou internacionais. Ademais, a história mostra que há regressões em relação a direitos consolidados, bem como direitos que em uma sociedade são aceitos e garantidos como tais e, em outra são desconsiderados ou considerados em desacordo com sua formação social e identidade cultural. Cabe considerar que, onde ocorrem, os direitos são indivisíveis ou ao menos interdependentes, como é o caso dos direitos à vida e à liberdade de expressão, que ficam comprometidos ou inviáveis sem os direitos à renda, à saúde e à educação, por exemplo. Sendo assim, é preferível tratar dos direitos como dimensões dos direitos humanos (dimensão civil, política, social, etc.). Mas, tal articulação está longe de significar que são compatíveis teoricamente, ideologicamente ou no plano da legislação e implementação de políticas e das lutas sociais. Por exemplo, a sustentação de direitos liberais na escala da economia não é necessariamente acompanhada pela garantia de direitos liberais no âmbito dos costumes (livre orientação sexual ou diversidade étnico-cultural, por exemplo); a lógica dos direito civis conflita com a dos direitos sociais ${ }^{9}$.

Setores de esquerda criticam reivindicações por direitos sociais e serviços públicos concernentes (escola, habitação social, unidades de saúde e assistência social entre outros) por desviarem-se das lutas revolucionárias e pela emancipação humana (MOTTA, 2011; DoIMO, 1995). Como para Marx (1987) o alcance dos direitos pertinentes e procedentes da revolução burguesa é a emancipação política, a crítica de uma linhagem marxista aos direitos assenta-se no seu limite para superar a desigualdade fundamentada no modo de produção (LENHART, e OFFE, 1984).

algumas dimensões das instituições e de organização do sistema estatal de proteção social, porém, por um lado, mudanças ocorreram de acordo com o modelo de Estado de Bem Estar pré-existente e, por outro, traços de permanência são identificáveis (DRAIBE, 2003, p. 64).

$9 \mathrm{O}$ reconhecimento dos direitos sociais "requer uma intervenção ativa do Estado, que não é requerida pela proteção dos direitos de liberdade, produzindo aquela organização dos serviços públicos de onde nasceu até mesmo uma nova forma de Estado, o Estado social. Enquanto os direitos de liberdade nascem contra o superpoder do Estado - portanto, com o objetivo de limitar o poder - os direitos sociais exigem, para sua realização prática, ou seja, para a passagem da declaração puramente verbal à sua proteção efetiva, precisamente o contrário..." (BoвBı, 1992, p. 72). 
OPINIÃO PÚBLICA, Campinas, vol. 18, n², novembro, 2012, p. 309-336

De toda maneira, nas sociedades que vivenciaram os "ecos da Marselhesa"10, os direitos humanos são parte tanto dos ideários liberais como de justiça social e econômica e estão inseridos nas instituições e cultura política de Estados e internacionalmente. Porém, entendo-os não como base para julgamentos fundamentados em supostas verdades universais, mas, sim para análises históricas e comparativas entre sociedades e grupos sociais específicos.

\section{Aspectos metodológicos}

A pesquisa foi realizada em Curitiba, onde foram entrevistados 35 dos 38 vereadores da gestão 2009-2012 ${ }^{11}$. O roteiro da entrevista semiestruturada foi organizado com blocos de questões sobre vinculação partidária e associativismo, conhecimento da legislação social e sobre valores políticos e a respeito dos direitos sociais, havendo ainda questões de controle ligadas ao perfil educacional, religião e renda.

Neste artigo, são apresentados resultados sobre questões referentes a valores sobre direitos sociais. Foram realizados testes de independência Q de Yule e de correlação Q de Yule, indicados para a análise de dados categóricos. Estes testes exigem o agrupamento de casos em tabelas quádruplas, o mais adequado para a pesquisa, já que as respostas das entrevistas apresentaram alto grau de dispersão entre as alternativas, embora, também, exija concentração dos dados e, com isso, há menor detalhamento.

A discussão é norteada pelos artigos constitucionais e pela tipologia de solidariedade elaborada para este fim. Esta elaboração levou em conta que, para Weber, tipos ideais são construções conceituais que retêm traços típicos de fenômenos ou processos sociais a partir da observação de casos históricos particulares e da lógica da comparação, em que se opera indutivamente o descarte do que é particular ou singular a cada caso e retém-se o que é passível de generalização.

Portanto, como parâmetro e medidor para comparações e análises sobre valores políticos e comportamento, elaborei os seguintes tipos de solidariedade no campo dos direitos sociais: civil-pública; cívica-protetiva; pessoalista, benevolente; internacional e cosmopolita.

Tipos de solidariedade no campo dos direitos sociais ${ }^{12}$ :

1. Solidariedade civil-pública: identificada quando os valores dos agentes demonstram adesão à prestação e à provisão social pelo Estado ou sob a regulação estatal, direcionadas pela legislação social com o registro dos direitos e da impessoalidade de cidadania. Isto é, regulação e sentido públicos ainda

\footnotetext{
10 Em alusão ao livro de Hobsbawm (1996) sobre a Revolução Francesa e suas repercussões e espraiamento para parte do mundo. Dimensões sociais, civis e políticas dos direitos humanos estavam na Declaração dos Direitos do Homem e do Cidadão de 1789, posteriormente, na Declaração dos Direitos Humanos de 1948, e foram se consolidando de forma mais ou menos incremental em declarações posteriores sobre direitos culturais, econômicos e ambientais.

11 Para a realização das entrevistas agradeço as contribuições de Talita Nascimento, Paulo Roberto R. Hannesch, Simone de Cássia S. da Silva e Sabrina Lissa F. L. Leme, aluno (a)s do Curso de Sociologia da PUCPR, sendo os dois primeiros bolsistas PIBIC. As tabelas foram geradas por Talita Nascimento por meio do programa SPSS e formatadas por Pedro Boscardin (PIBICjr).

12 Essa, como qualquer classificação, organiza e reduz a diversidade empírica em conjuntos amplos por afinidade de elementos que são próprios ao fenômeno definido, elementos esses que o pesquisador elege como significativos, nesse caso, a distância e a proximidade com a noção de direito social. Os nomes mais adequados ao conteúdo de cada tipo de solidariedade estão em fase de aprimoramento.
} 
KAUCHAKJE, S. Solidariedade e expressão jurídica: valores políticos de vereadores...

quando as ações sociais são realizadas por agentes ou organizações não governamentais. Valores que se opõem à benevolência e à motivação de caridade e filantropia desvinculadas da noção de direitos.

2. Solidariedade cívica-protetiva: combina valores favoráveis aos laços sociais de confiança, no sentido do capital social em Putnam (2000) e Bourdieu (1998); e ao ativismo político com confiança nas instituições e classe política, no sentido da cultura cívica aludida em Almond e Verba (1989). Neste tipo de solidariedade, prevalece a noção de que pessoas e comunidades intervencionadas são sujeitos de direitos e não sujeitados às práticas caritativas. Tais noções são opostas à de um "terceiro setor" benevolente que busca os recursos do Estado numa espécie de negócio e, também, de refilantropização da questão social ${ }^{13}$.

3. Solidariedade pessoalista: orienta ações protetivas restritas aos laços e redes pessoalizadas e particularistas (territoriais ou não) e defensivas (de desconfiança dos que estão fora do círculo pessoalparticularizado). Solidariedade típica do período pré-moderno, de sociedades tradicionais, mas, também, identificável na atualidade em localidades e comunidades (não necessariamente delimitadas territorialmente) onde a ausência ou insuficiência de políticas públicas impele para a proteção social ${ }^{14}$ por meio de laços de filiação, de lealdade e confiança mútua que não ultrapassam os círculos familiares, de vizinhança e de igrejas, conforme a noção de familismo amoral a que se referiam Banfield (1958) e Putnam (2000). O interesse pelas questões públicas é baixo e, quando há, o objetivo é obter ganhos privados. Cabe ressaltar que quando a relação é entre atores políticos e a população (principalmente pessoas com baixa renda), este tipo de solidariedade aproxima-se do clientelismo. Lembrando com Carvalho (1997) e Lopez (2004) que, neste caso, o clientelismo baseia-se na distribuição de benefício e favor que sedimentam dependência política e retribuição na forma de fidelidade e apoio eleitoral.

4. Solidariedade benevolente: concentra valores de caridade, filantropia e doação que, geralmente, concretizam-se em ações voltadas para pessoas empobrecidas, em situação de indigência ou discriminação, entendidas como carentes e marginalizados ou outras figuras que os destituem da condição de cidadãos e expressam o não reconhecimento de relações mediadas por garantias públicas. A interação é caracterizada pela "suplicação vertical" (PUTNAM, 2000) do beneficiário e manifestação de superioridade (de bens e, não raro, aceitos como de caráter) do benévolo. Dito de outro modo, a relação mediada pela "doação sem reciprocidade, que só permite, como única volta, uma gratidão sem limites" (LAVILLE, 2008, p. 23) transforma a justiça em caridade e os direitos em ajuda (TELLES, 2000). Ações motivadas pela solidariedade benevolente podem ser destinadas a pessoas, grupos, comunidades e sociedades locais ou estrangeiras e numa perspectiva global-humanitária.

5. Solidariedade internacional: caracteriza valores estatalistas ${ }^{15}$ que, nas relações internacionais, firmam o apego ao preceito da soberania dos Estados no que diz respeito à dimensão social dos direitos humanos. Isto é, no plano internacional, os direitos não têm caráter de exigência jurídica ou de

\footnotetext{
13 Uma discussão sobre a refilantropização da questão social e ONGs encontra-se, por exemplo, em Raichellis (2006).

14 Aquisição de bens materiais e imateriais ligados à assistência social, saúde, cultura, entre outros.

15 Concordo com Koerner que prefere "a expressão estatalismo a estatismo para evitar a conotação de intervenção do Estado na economia ou sociedade [...]. a discussão remete às relações Estado-ordem internacional e não Estado-economia/sociedade, (KoeRner. 2002, p. 96).
} 
OPINIÃO PÚBLICA, Campinas, vol. 18, no 2, novembro, 2012, p. 309-336

justificação para intervenções, cabendo tão somente a colaboração e o incentivo para que os parâmetros dos direitos humanos sejam incorporados na legislação e na implementação de políticas públicas no interior de cada país (KOERNER, 2002).

6. Solidariedade cosmopolita: valores que expressam o compromisso com o direito internacional dos direitos humanos. São admitidas as normas, sanções e intervenções internacionais para o respeito e responsabilidade com as dimensões civil, política, social e ambiental dos direitos, o que, por um lado, coloca em questão a soberania do Estado e, por outro, coloca a questão do intervencionismo etnocentrado (parâmetros ocidentais sobre direitos, especialmente). Isso significa que a comunidade política delimitada, ou a vinculação com um determinado Estado, não é critério para a exclusão das garantias internacionais (VILLA, 2008). Ou, em outras palavras, os direitos humanos são considerados inerentes aos seres humanos, "independentemente de vinculação a um determinado Estado" (ABREU, 2007, p. 5).

As características de cada tipo permitem fusioná-los em dois grandes tipos: solidariedade política e solidariedade da dádiva ${ }^{16}$. A solidariedade política tem o sentido da validação subjetiva da norma jurídica ${ }^{17}$ ou, mais amplamente, de adesão cognitiva e afetiva aos direitos e garantias de proteção social públicas, baseada nos laços e reconhecimento de cidadania local ou planetária. A solidariedade da dádiva tem o sentido estrito de donativo ${ }^{18}$ no qual dar "é manifestar superioridade, é ser mais, mais elevado, magister; aceitar sem retribuir, ou sem retribuir mais, é subordinar-se, tornar-se cliente e servidor, ser pequeno, ficar mais abaixo (minister)" (MAUSS, 2003, p. 305).

Idealmente, fazem parte do conjunto da solidariedade política os tipos: civil-pública, cívicaprotetiva, internacional, cosmopolita; compõe o conjunto da solidariedade da dádiva os tipos de solidariedade pessoalista e benevolente. Os valores que as caracterizam podem orientar condutas no campo dos direitos sociais.

\section{Perfil social, partidário e ideológico dos vereadores em Curitiba}

Mais da metade $(62,9 \%)$ dos parlamentares entrevistados têm ensino superior completo ou pós-graduação, apenas um deles cursou o ensino médio incompleto e o restante possui ensino médio ou superior incompleto. Mais de 70\% têm entre 30 e 64 anos e, desses, a maioria (48,6\%) tem entre 40 e 54 anos. O maior número de vereadores é filiado ao PSDB (40,0\%). Em seguida, o PT, PDT e DEM têm, cada um, $86 \%$ dos vereadores; o PMDB, 5,7\% (Tabela 1):

\footnotetext{
16 Estas nomenclaturas ou suas variações, com sentidos similares, são encontradas em Souza (2002), Vasconcelos (2007) e, também, entre vários autores citados na exposição das características de cada tipo.

17 Weber considera que a sociologia "se pergunta sobre o que de fato ocorre em uma comunidade em razão de que exista a probabilidade de que os homens que participam da atividade comunitária, sobretudo aqueles que podem influenciar consideravelmente essa atividade, considerem subjetivamente válida uma determinada ordem e orientem por ela a sua conduta prática" (WEBER, 1984, p. 251)

18 Esta tipologia não lida com as consequências teóricas e analíticas do conceito de dádiva em Mauss ou em Bourdieu (2007), mas, apenas assume alguns de seus elementos para o campo dos direitos sociais.
} 
KAUCHAKJE, S. Solidariedade e expressão jurídica: valores políticos de vereadores...

\section{Tabela 1 \\ Partidos políticos de vereadores de Curitiba \\ Gestão 2009 - 2012}

\begin{tabular}{|l|c|c|c|}
\hline \multicolumn{1}{|c|}{ PARTIDOS POLÍTICOS } & Frequência & Proporção & Porcentagem \\
\hline DEM - Democratas & 3 & 0,09 & 8,6 \\
\hline PDT - Partido Democrático Trabalhista & 3 & 0,09 & 8,6 \\
PMDB - Partido do Movimento Democrático Brasileiro & 2 & 0,06 & 5,7 \\
\hline PP - Partido Progressista & 1 & 0,03 & 2,9 \\
PPS - Partido Popular Socialista & 2 & 0,06 & 5,7 \\
PRP - Partido Republicano Progressista & 1 & 0,03 & 2,9 \\
PSB - Partido Socialista Brasileiro & 3 & 0,09 & 8,6 \\
\hline PSC - Partido Social Cristão & 1 & 0,03 & 2,9 \\
PSDB - Partido da Social Democracia Brasileira & 14 & 0,4 & 40,0 \\
PSL - Partido Social Liberal & 1 & 0,03 & 2,9 \\
PT - Partido dos Trabalhadores & 3 & 0,09 & 8,6 \\
PV - Partido Verde & 1 & 0,03 & 2,9 \\
\hline
\end{tabular}

Obs. Estão destacados em cinza os partidos agrupados como esquerda e centro-esquerda e sem destaque os partidos considerados de direita e centro-direita, conforme a literatura ${ }^{19}$

O perfil ideológico dos parlamentares municipais de Curitiba fica evidenciado pelo agrupamento dos partidos considerados de direita e centro-direita - 21 (60\%) - e de esquerda e centro-esquerda - 14 $(40 \%)^{20}$ (Tabela 1). Um critério substantivo da classificação de direita e esquerda é a maior afinidade com liberdade ou com a igualdade, respectivamente (BOBBIO, 1995; SINGER, 2000). A partir deste critério os parlamentares foram interrogados sobre hierarquias sociais (Tabela 2):

\footnotetext{
19 Em Miguel e Machado (2007), partidos de esquerda: PT, PCB, PC do B, PCO, PDT, PHS, PMN, PPS, PSB, PSTU e PV; de centro: PMDB e PSDB; de direita: PFL, PL, PPB e PTB, além de PAN, PGT, PRN, Prona, PRTB, PSC, PSD, PSDC, PSL, PSN, PST, PT do B e PTN. Em Carreirão (2006), direita: PP (PPB; PPR; PDS); PFL; PRN; PDC; PL; PTB; PSC; PSP; PRP; PSL; PSD e PRONA; centro: PMDB e PSDB; esquerda: PT; PDT; PPS; PCdoB; PSB; PV; PSTU; PCO e PMN.

20 O perfil ideológico do PMDB é diverso a depender do local e período de análise (BRAGA, 2006). No Paraná, o PMDB pode ser alinhado como centro junto aos partidos de esquerda, o que é corroborado por Perissinotto e Braunert (2006) e Perissionotto, Codato, Fuks e Braga (2007). Portanto, para diferenciar os partidos de centro, o PMDB será classificado como de centroesquerda e o PSDB como de centro-direita.
} 
OPINIÃO PÚBLICA, Campinas, vol. 18, no 2, novembro, 2012, p. 309-336

Tabela 2

Valores dos vereadores Curitiba por filiação partidária, sobre hierarquia social Gestão 2009.2012

\begin{tabular}{|c|c|c|c|c|c|c|c|c|}
\hline \multirow{2}{*}{ Partidos } & \multicolumn{6}{|c|}{ "Sem hierarquias sociais bem definidas nenhuma ordem se sustenta" } \\
\cline { 2 - 9 } & $\begin{array}{c}\text { Discorda } \\
\text { Totalmente ou } \\
\text { em parte }\end{array}$ & \multicolumn{2}{c|}{$\begin{array}{c}\text { Concorda } \\
\text { Totalmente ou } \\
\text { em parte }\end{array}$} & \multicolumn{2}{c|}{$\begin{array}{c}\text { Não sabe } \\
\text { ou } \\
\text { não respondeu }\end{array}$} & \multicolumn{2}{c|}{ TOTAL } \\
\cline { 2 - 9 } & N & $\%$ & N & $\%$ & N & $\%$ & N & $\%$ \\
\hline DEM & 0 & 0 & 3 & 100,0 & 0 & 0 & 3 & 100,0 \\
PDT & 0 & 0 & 3 & 100,0 & 0 & 0 & 3 & 100,0 \\
PMDB & 1 & 50,0 & 1 & 50,0 & 0 & 0 & 2 & 100,0 \\
PP & 0 & 0 & 1 & 100,0 & 0 & 0 & 1 & 100,0 \\
PPS & 0 & 0 & 2 & 100,0 & 0 & 0 & 2 & 100,0 \\
PRP & 0 & 0 & 1 & 100,0 & 0 & 0 & 1 & 100,0 \\
PSB & 0 & 0 & 2 & 66,6 & 1 & 33,0 & 3 & 100,0 \\
PSC & 1 & 100,0 & 0 & 0 & 0 & 0 & 1 & 100,0 \\
PSDB & 5 & 35,7 & 9 & 64,3 & 0 & 0 & 14 & 100,0 \\
PSL & 0 & 0 & 1 & 100,0 & 0 & 0 & 1 & 100,0 \\
PT & 3 & 100,0 & 0 & 0 & 0 & 0 & 3 & 100,0 \\
PV & 0 & 0 & 0 & 0 & 1 & 100,0 & 1 & 100,0 \\
TOTAL & 10 & 28,6 & 23 & 65,7 & 2 & 5,7 & 35 & 100,0 \\
\hline
\end{tabular}

A maioria dos vereadores $(65,7 \%)$ concorda com a afirmação de que "sem hierarquias bem definidas nenhuma ordem social se sustenta" e $28,6 \%$ discordam. A porcentagem de vereadores que manifesta valores com baixa congruência em relação ao critério da igualdade ultrapassa a daqueles filiados aos partidos de direita e centro - direita $^{21}$ (Tabela 3):

21 Este agrupamento permite a realização de testes de independência e de correlação $Q$ de Yule que requerem tabelas quádruplas e frequências em cada casela da tabela de distribuição iguais ou superiores a cinco. Os testes foram realizados a despeito de uma das casas da tabela quádrupla ter valor menor que 5, pois, embora não recomendável, considero que os resultados fornecem indicativos úteis para a discussão. 
KAUCHAKJE, S. Solidariedade e expressão jurídica: valores políticos de vereadores...

Tabela 3

Valores dos vereadores de Curitiba de partidos de direita/centro-direita ou esquerda/centro-esquerda sobre hierarquias social, econômica e política Gestão 2009.2012

\begin{tabular}{|c|c|c|c|c|c|c|}
\hline \multirow{2}{*}{$\begin{array}{l}\text { Sem hierarquias sociais bem definidas } \\
\text { nenhuma ordem se sustenta }\end{array}$} & \multicolumn{4}{|c|}{ Partido } \\
\cline { 2 - 7 } & \multicolumn{2}{|c|}{$\begin{array}{c}\text { Direita e } \\
\text { centro-direita }\end{array}$} & $\begin{array}{c}\text { Esquerda e } \\
\text { centro-esquerda }\end{array}$ & \multicolumn{2}{c|}{ Total } \\
\cline { 2 - 7 } & Frequência & $\%$ & Frequência & $\%$ & Frequência & $\%$ \\
\hline Concorda Totalmente ou em parte & 15 & 71,4 & 8 & 57,1 & 23 & 65,7 \\
Discorda Totalmente ou em parte & 6 & 28,6 & 4 & 28,6 & 10 & 28,6 \\
Não sabe ou não respondeu & 0 & 0 & 2 & 14,3 & 2 & 5,7 \\
Total & 21 & 100,0 & 14 & 100,0 & 35 & 100, \\
& & & & & & \\
\hline
\end{tabular}

Os testes demonstraram que há dependência estatística entre as variáveis no seguinte sentido: vereadores dos partidos de direita/centro-direita tendem a concordar com as hierarquias (teste de independência Q de Yule: delta 0,012) e há um menor número (do que o esperado, caso as variáveis fossem independentes) de vereadores dos partidos de esquerda/centro-esquerda que concordam (Tabela 4). Todavia, este resultado e o teste de correlação $Q$ de Yule $(0,11)$ indicam uma baixa correlação ${ }^{22}$ entre as variáveis, ou seja, há $11,0 \%$ de chance a mais de encontrar vereadores de direita e centro-direita que concordam com a importância das hierarquias sociais ${ }^{23}$.

Tabela 4

Teste de independência $Q$ de Yule para valores de vereadores de Curitiba (agrupados em perfil partidário) sobre hierarquia social Gestão 2009.2012

\begin{tabular}{|c|c|c|}
\hline \multirow{2}{*}{ Importância de hierarquia } & \multicolumn{2}{|c|}{ PARTIDO POLÍTICO } \\
\cline { 2 - 3 } & $\begin{array}{l}\text { Esquerda e } \\
\text { centro-esquerda }\end{array}$ & $\begin{array}{l}\text { Direita e } \\
\text { centro-direita }\end{array}$ \\
\hline Concorda & $\cdot$ & + \\
Discorda & + & + \\
\hline
\end{tabular}

Obs. A área sombreada servirá como referência para testes efetuados com outras variáveis cujos resultados apresentam o mesmo posicionamento dos sinais negativos e positivos.

\begin{abstract}
${ }^{22}$ A estimativa da força da correlação segue Meireles (2001). A despeito da correlação baixa, o resultado dos pares consistentes $(0,110)$ (par formado pelos vereadores de partidos de direita/centro-direita que concordam com as hierarquias e pelos vereadores de partidos de esquerda/centro-esquerda que discordam) é mais forte que o resultado dos pares inconsistentes $(0,088)$ (isto é, vereadores de partido de esquerda/centro-esquerda que concordam e vereadores de partidos de direita/centro. direita que discordam).

${ }^{23}$ A despeito da correlação baixa, o resultado dos pares consistentes $(0,110)$ (par formado pelos vereadores de partidos de direita/centro-direita que concordam com as hierarquias e pelos vereadores de partidos de esquerda/centro-esquerda que discordam) é mais forte que o resultado dos pares inconsistentes $(0,088)$ (isto é, vereadores de partido de esquerda/centro. esquerda que concordam e vereadores de partidos de direita/centro-direita que discordam).O teste demonstrou proximidade também entre o resultado para os pares consistentes $(0,12)$ (par formado pelos vereadores de partidos de direita/centro-direita que preferem a opção manter a ordem ou liberdade como principais responsabilidades do Estado e pelos parlamentares de partidos de esquerda/centro-esquerda que escolhem a alternativa garantir bem estar) e o resultado para os pares inconsistentes $(0,10)$ (vereadores de partidos de esquerda/centro-esquerda que preferem ordem ou liberdade e de partidos de direita/centro. direita que escolhem bem estar social).
\end{abstract}


OPINIÃO PÚBLICA, Campinas, vol. 18, no 2, novembro, 2012, p. 309-336

Outro modo de aferir o perfil ideológico dos parlamentares municipais é pela concepção sobre responsabilidade principal do Estado, a qual manifesta tendências mais conservadoras, liberais ou socializantes da democracia social e socialismo. As frequências seguem o mesmo padrão anterior. Porém, para este caso, acentuaram-se as ambiguidades entre valores constatados nas entrevistas e o perfil partidário-ideológico, cujo critério de classificação de direita é o maior apreço pela liberdade e o de esquerda é a preocupação com a igualdade (BOBBIO, 1995; SINGER, 2000). Alguns partidos situados à esquerda/centro-esquerda priorizam a manutenção da ordem ou as liberdades individuais e alguns à direita/centro-direita escolhem o bem estar social como responsabilidade estatal prioritária (Tabela 5):

Tabela 5

Escolha dos vereadores de Curitiba por filiação partidária, sobre responsabilidade principal do Estado

Gestão 2009.2012

\begin{tabular}{|c|c|c|c|c|c|c|c|c|}
\hline \multirow[t]{3}{*}{ Partidos } & \multicolumn{8}{|c|}{ Responsabilidade principal do Estado } \\
\hline & \multicolumn{2}{|c|}{ Manter a ordem } & \multicolumn{2}{|c|}{$\begin{array}{l}\text { Respeitar } \\
\text { liberdades } \\
\text { individuais }\end{array}$} & \multicolumn{2}{|c|}{$\begin{array}{c}\text { Garantir bem estar } \\
\text { social }\end{array}$} & \multicolumn{2}{|c|}{ TOTAL } \\
\hline & $\mathrm{N}$ & $\%$ & $\mathrm{~N}$ & $\%$ & $\mathrm{~N}$ & $\%$ & $\mathrm{~N}$ & $\%$ \\
\hline DEM & 3 & 100,0 & 0 & 0 & 0 & 0 & 3 & 100,0 \\
\hline PDT & 2 & 66,7 & 1 & 33,3 & 0 & 0 & 3 & 100,0 \\
\hline PMDB & 0 & 0 & 0 & 0 & 2 & 100,0 & 2 & 100,0 \\
\hline PP & 0 & 0 & 0 & 0 & 1 & 100,0 & 1 & 100,0 \\
\hline PPS & 1 & 50,0 & 1 & 50,0 & 0 & 0 & 2 & 100,0 \\
\hline PRP & 0 & 0 & 0 & 0 & 1 & 100,0 & 1 & 100,0 \\
\hline PSB & 2 & 66,7 & 0 & 0 & 0 & 0 & $3^{*}$ & 100,0 \\
\hline PSC & 0 & 0 & 1 & 100,0 & 0 & 0 & 1 & 100,0 \\
\hline PSDB & 4 & 28,6 & 5 & 35,7 & 4 & 28,6 & $14^{*}$ & 100,0 \\
\hline PSL & 0 & 0 & 0 & 0 & 1 & 100,0 & 1 & 100,0 \\
\hline PT & 0 & 0 & 0 & 0 & 3 & 100,0 & 3 & 100,0 \\
\hline PV & 0 & 0 & 1 & 100,0 & 0 & 0 & 1 & 100,0 \\
\hline TOTAL & 12 & 34,3 & 09 & 25,7 & 12 & 34,3 & $35^{*}$ & 100,0 \\
\hline
\end{tabular}

*Resposta anulada: PSB-01; PSDB-01

Para tratar este ponto, as alternativas "manter a ordem" e "respeitar liberdades individuais" foram conjugadas, porque, por um lado, a maior parte das posições dos vereadores, por partidos, dividese entre estas alternativas (exceto para o caso do PSDB), e por outro, para isolar a opção "garantir bem estar social", afeita aos direitos sociais. Com isso, verifica-se que $60 \%$ escolheram manter a ordem ou respeitar a liberdade individual e 34,3\% garantir bem estar social (Tabelas 5 e 6). 
KAUCHAKJE, S. Solidariedade e expressão jurídica: valores políticos de vereadores...

Tabela 6

Valores dos vereadores de Curitiba de partidos de direita/centro-direita ou esquerda/centro-esquerda, sobre principal responsabilidade do Estado

Gestão 2009-2012

\begin{tabular}{|c|c|c|c|c|c|c|}
\hline \multirow{2}{*}{$\begin{array}{l}\text { Principal responsabilidade do } \\
\text { Estado }\end{array}$} & \multicolumn{4}{|c|}{ Partido } \\
\cline { 2 - 7 } & \multicolumn{2}{|c|}{$\begin{array}{c}\text { Direita e } \\
\text { centro-direita }\end{array}$} & $\begin{array}{c}\text { Esquerda e } \\
\text { centro-esquerda }\end{array}$ & \multicolumn{2}{c|}{ Total } \\
\cline { 2 - 7 } & Frequência & $\%$ & Frequência & $\%$ & Frequência & $\%$ \\
\hline $\begin{array}{c}\text { Manter a ordem ou respeitar } \\
\text { liberdades individuais }\end{array}$ & 13 & 61,9 & 8 & 57,1 & 21 & 60,0 \\
Garantir bem estar social & 7 & 33,3 & 5 & 35,7 & 12 & 34,3 \\
Não sabe ou não respondeu & 1 & 4,8 & 1 & 4,8 & 2 & 5,7 \\
Total & 21 & 100,0 & 14 & 100,0 & 35 & 100,0 \\
\hline
\end{tabular}

Obs. Colunas em destaque para a realização dos testes de independência Q de Yule e de correlação Q de Yule

Os testes indicaram que as variáveis partido e responsabilidade do Estado podem ser consideradas independentes (delta 0,009). No entanto, admitindo-se a desprezível dependência estatística, o seu sentido é de que os vereadores dos partidos de direita/centro-direita tendem a escolher as alternativas "manter a ordem" ou "respeitar a liberdade individual". Este resultado é confirmado pela correlação baixíssima (0,074), demonstrando que há 7,4\% de chance a mais de encontrar vereadores de direita/centro-direita com preferência pela alternativa "manter a ordem" ou "respeitar a liberdade individual" 24 .

As correlações entre perfil ideológico-partidário com a variável hierarquia social e com a variável responsabilidade do Estado foram frágeis. Isto, por um lado, coloca a questão se o "continuum esquerda-direita como referencial para a análise" está perdendo importância para a compreensão do "comportamento dos partidos e seus membros" (CARREIRÃo, 2006, p. 159) e, por outro, pode ser mais um indicador "da perda de centralidade dos partidos do ponto de vista da reconfiguração da representação"25 (LAVALLE, HOUTZAGER, CASTELLO, 2006, p. 68).

\footnotetext{
$24 \mathrm{O}$ teste demonstrou proximidade também entre o resultado para os pares consistentes $(0,12)($ par formado pelos vereadores de partidos de direita/centro-direita que preferem a opção manter a ordem ou liberdade como principais responsabilidades do Estado e pelos parlamentares de partidos de esquerda/centro-esquerda que escolhem a alternativa garantir bem estar) e o resultado para os pares inconsistentes $(0,10)$ (vereadores de partidos de esquerda/centro-esquerda que preferem ordem ou liberdade e de partidos de direita/centro-direita que escolhem bem estar social).Para Lavalle (2006, p. 84) a perda de centralidade dos partidos políticos faz parte da reconfiguração da representação em curso decorrente dos seguintes fatores: as "novas instâncias de mediação entre representantes e representados: a mídia, é claro, mas não só, também constelações de atores intermediários não mais ordenáveis pelas grandes clivagens ideológicas e socioeconômicas das democracias de partidos de massas" e; "a multiplicação de instâncias de participação cidadã e de representação coletiva incumbidas da definição de prioridades públicas e do desenho e supervisão de políticas."

25 Para Lavalle, Houtzager e Castello, a perda de centralidade dos partidos políticos faz parte da reconfiguração da representação em curso decorrente dos seguintes fatores: as "novas instâncias de mediação entre representantes e representados: a mídia, é claro, mas não só, também constelações de atores intermediários não mais ordenáveis pelas grandes clivagens ideológicas e socioeconômicas das democracias de partidos de massas" e; "a multiplicação de instâncias de participação cidadã e de representação coletiva incumbidas da definição de prioridades públicas e do desenho e supervisão de políticas" (LAVALLE, Houtzager e CAstello, 2006, p. 84).
} 
OPINIÃO PÚBLICA, Campinas, vol. 18, no 2, novembro, 2012, p. 309-336

De modo geral, a composição partidária da Câmara dos Vereadores de Curitiba da gestão em foco, os valores sobre hierarquia social e responsabilidade principal do Estado, assim como a correlação entre estas variáveis apontam para um perfil ideológico liberal e conservador. Esta concepção, por sua vez, contribui para entender os valores dos vereadores sobre direitos sociais.

\section{Valores sobre direitos sociais e concepções de solidariedade}

Os vereadores de Curitiba foram estimulados a escolher quais entre os seguintes itens considerariam como direitos sociais: saúde, previdência social, educação, assistência social, segurança alimentar e nutricional, trabalho, transferência de renda e habitação.

Tais áreas constam, principalmente, no Título II (Dos Direitos e Garantias Fundamentais) e no Título VIII da Ordem social da CF88 Federal e nas leis referentes ${ }^{26}$. Quando se trata dos direitos sociais em conjunto, as respostas dos parlamentares sugerem valores não inteiramente condizentes com a solidariedade política, mas, quando observados separadamente, verifica-se maior congruência com este tipo de solidariedade para os casos da saúde, educação e previdência social e menor compatibilidade para segurança alimentar e nutricional, assistência social e transferência de renda (Tabela 7):

Tabela 7

Áreas reconhecidas como direitos sociais pelos vereadores de Curitiba Gestão 2009-2012

\begin{tabular}{|c|c|c|c|c|c|c|c|c|c|c|}
\hline \multirow{2}{*}{ Direitos } & \multicolumn{2}{|c|}{ Sim } & \multicolumn{2}{|c|}{ Não } & \multicolumn{2}{|c|}{ NR } & \multicolumn{2}{|c|}{ RN } & \multicolumn{2}{|c|}{ Total } \\
\hline & $\mathrm{N}$ & $\%$ & $\mathrm{~N}$ & $\%$ & N & $\%$ & $\mathrm{~N}$ & $\%$ & $\mathrm{~N}$ & $\%$ \\
\hline Saúde & 33 & 94,3 & 0 & 0 & 0 & 0 & 2 & 5,7 & 35 & 100,0 \\
\hline Educação & 32 & 91,4 & 1 & 2,9 & 0 & 0 & 2 & 5,7 & 35 & 100,0 \\
\hline Previdência social & 32 & 91,4 & 1 & 2,9 & 0 & 0 & 2 & 5,7 & 35 & 100,0 \\
\hline Trabalho & 31 & 88,8 & 2 & 5,7 & 0 & 0 & 2 & 5,7 & 35 & 100,0 \\
\hline Habitação & 30 & 85,7 & 3 & 8,6 & 0 & 0 & 2 & 5,7 & 35 & 100,0 \\
\hline Segurança alimentar & 28 & 80,0 & 5 & 14,3 & 0 & 0 & 2 & 5,7 & 35 & 100,0 \\
\hline Assistência social & 27 & 77,1 & 6 & 17,1 & 0 & 0 & 2 & 5,7 & 35 & 100,0 \\
\hline Transferência de renda & 16 & 45,7 & 17 & 48,6 & 0 & 0 & 2 & 5,7 & 35 & 100,0 \\
\hline
\end{tabular}

Os valores dos vereadores são pertinentes à própria história dos direitos sociais. No final do século XIX e primeira metade do século XX, o núcleo da legislação social era saúde, previdência social, educação, trabalho (mais especificamente: leis trabalhistas regulando salários, relações e condições de

26 “Por exemplo, Lei Orgânica da Saúde (Lei n 8.080/1990); Lei Orgânica da Assistência Social (Lei n 8.742/1993); Renda de Cidadania (Lei $n^{\circ}$ 10.835/2004); Programa Bolsa Família (Lei $\left.n^{\circ} 10.836 / 2004\right)$; Lei de Diretrizes e Bases da Educação (Lei $n^{\circ}$ 9.394/96); Lei sobre habitação de interesse social (Lei $n^{\circ}$ 11.124/2005); Lei do Sistema Nacional de Segurança Alimentar e Nutricional (Lei n 11.346/2006). 
KAUCHAKJE, S. Solidariedade e expressão jurídica: valores políticos de vereadores...

trabalho) e assistência (neste período, aceita menos como direito e mais como ajuda aos empobrecidos e incapacitados para o trabalho).

Durante o século XX e início do XXI, o rol dos direitos sociais foi ampliado com os direitos ao lazer, transferência de renda (nas variações renda de cidadania com sentido da universalidade e renda mínima garantida focalizada nas pessoas de baixa renda ${ }^{27}$ ), assistência social, trabalho como um bem social e segurança alimentar e nutricional, por exemplo (DRAIBE, 1989, CASTRO et al, 2009).

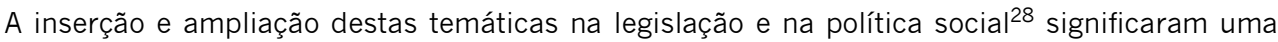
inflexão no padrão institucional do Estado de Bem Estar Social brasileiro, o qual, até meados de 1980, era concernente ao modelo meritocrático-particulatista ou conservador ${ }^{29}$. Atualmente, esta legislação e política social apontam numa direção mais universalista (DRAIBE, 1993a, FIORI, 1997), o que pode vir a contribuir para modelar a cultura política brasileira também neste sentido ${ }^{30}$.

Todavia, como já mencionado, os valores de parte dos vereadores demonstram que esta influência não é acentuada no caso de valores sobre direitos mais recentes, pois, quase metade (48,6\%) não considera que transferência de renda seja um direito social; $17,1 \%$ excluem do conjunto desses direitos a assistência social e 14,3\% não reconhecem como um direito às seguranças alimentar e nutricional (Tabela 7).

\section{Valores sobre programa de transferência de renda e perfil ideológico}

Transferência de renda apresentou menor validação subjetiva como um direito, por isso, seu detalhamento pode fornecer sugestões para a discussão sobre os demais direitos sociais. Esta área dos direitos tem, também, a maior rejeição ao longo da história da cidadania social desde suas protoformas no século XVI e da política social no XIX, cujas medidas assistenciais destinadas às camadas empobrecidas primavam pelo caráter provisório e reduzido, a fim de não competir com a aceitação de trabalho, mesmo aqueles com condições salariais, de jornada e salubridade consideradas deploráveis já entre autores do século XIX (MARX, 1980; HugO, 2002; CASTEL, 2001; CARVALHO, 2001).

Interessante notar que outros dados das entrevistas reforçam esta compatibilidade dos valores com a história dos direitos sociais, mesmo quando os dados indicam uma aparente contradição. Chama

\footnotetext{
27 Atualmente, no Brasil, os principais programas de transferência de renda são o Benefício de Prestação Continuada (BPC) e o Programa Bolsa Família (PBF), os quais podem ser classificados como programas de renda mínima com foco nos grupos populacionais de baixa renda. Uma das críticas a estes programas é a focalização agravada pelo corte de renda muito baixo (pessoas em situação de miserabilidade), outras, contrariamente, apontam o incentivo à desídia como efeito perverso de programas aos moldes do BF (FIGUEIREDO, 2006).

28 Prefiro utilizar o termo política social, no singular, que enfatiza tratar de uma política pública que abarca diferentes setores (políticas sociais específicas), tais como, educação, assistência social, saúde, etc. (DralBE, 1993a).

29 Vale lembrar que entre os modelos de Bem Estar Social, tratados especialmente por Esping.Andersen (1991), o modelo conservador repousa na premissa "de que as pessoas devem estar em condições de resolver suas próprias necessidades, com base em seu trabalho, em seu mérito, no desempenho profissional, na sua produtividade. A política social intervém apenas parcialmente, completando e corrigindo as ações alocativas do mercado e as instituições econômicas. Esping-Andersen chama a atenção para as características histórico-constitutivas desse padrão, que vincula ao emprego o acesso aos benefícios. Antes de tudo, esse é um sistema corporativo e estratificado, no qual tendem a coexistir distintos sistemas previsionais criados pelo Estado para diferentes categorias ocupacionais, os trabalhadores, os empregados "white collor", os funcionários públicos, os militares, dentre outros" (DRAIBE, 1993b, p. 7).

${ }^{30} \mathrm{O}$ alcance e impacto dessa inflexão na tessitura social, em particular nos aspectos econômicos e da cultura política, são discutidos por autores como Oliveira (2003), Neri (2007, 2011), Medeiros et al (2007) e Castro et al (2009).
} 
OPINIÃO PÚBLICA, Campinas, vol. 18, no 2, novembro, 2012, p. 309-336

a atenção que $88,5 \%$ dos vereadores concordaram com a afirmação que os programas de transferência de renda são necessários para atender carências ou ativar a economia, mesmo que possam provocar a ineficiência do Estado (Tabela 8):

Tabela 8

Opiniões de vereadores de Curitiba sobre políticas e programas de transferência de renda Gestão 2009.2012

\begin{tabular}{|c|c|c|c|}
\hline Políticas e programas de transferência de renda & Frequência & Proporção & Porcentagem \\
\hline $\begin{array}{l}\text { Em geral provocam a ineficiência econômica do Estado e devem ser } \\
\text { evitadas }\end{array}$ & 4 & 0,11 & 11,4 \\
\hline $\begin{array}{l}\text { São necessárias para atender carências sociais, mesmo que } \\
\text { provoquem ineficiência econômica do Estado }\end{array}$ & 25 & 0,7 & 71,4 \\
\hline $\begin{array}{l}\text { São necessárias porque ativam a economia local, mesmo que } \\
\text { provoquem a ineficiência econômica do Estado }\end{array}$ & 6 & 0,17 & 17,1 \\
\hline TOTAL & 35 & 1,0 & 100,0 \\
\hline
\end{tabular}

Entretanto, 65,8\% discordaram totalmente ou em parte que programas de transferência de renda sejam incorporados na legislação social, o que é compatível com os resultados de não reconhecimento da área como um direito e indica a tendência em aceitar tais ações desde que sejam como doação e não como direito de cidadania. A aceitação por $71,4 \%$ dos vereadores da necessidade de atender carências sociais corrobora esta tendência (Tabelas 8 e 9). Tais dados vão ao encontro dos argumentos de Reis (1995) sobre a cultura de responsabilidade benevolente das elites brasileiras e, portanto, sugerem valores condizentes com a solidariedade benevolente.

Tabela 9

Opiniões de vereadores de Curitiba sobre a natureza dos programas de transferência de renda e legislação Gestão 2009.2012

\begin{tabular}{|c|c|c|c|}
\hline $\begin{array}{l}\text { Inscrição de programas de transferência de renda na } \\
\text { legislação como direito de cidadania }\end{array}$ & Frequência & Proporção & Porcentagem \\
\hline Discorda totalmente & 15 & 0,42 & 42,9 \\
\hline Discorda em parte & 8 & 0,22 & 22,9 \\
\hline Concorda em parte & 5 & 0,14 & 14,3 \\
\hline Concorda totalmente & 7 & 0,2 & 20,0 \\
\hline TOTAL & 35 & 1,0 & 100,0 \\
\hline
\end{tabular}

Uma justificativa para esta opinião relaciona-se ao fato de que de $65,7 \%$ dos parlamentares consideram que programas sociais podem levar ao desestímulo para o trabalho (Tabela 10): 
KAUCHAKJE, S. Solidariedade e expressão jurídica: valores políticos de vereadores...

Tabela 10

Valores de vereadores de Curitiba por filiação partidária, sobre programas sociais e trabalho

Gestão 2009-2012

\begin{tabular}{|c|c|c|c|c|c|c|c|c|}
\hline \multirow[t]{3}{*}{ Partidos } & \multicolumn{8}{|c|}{$\begin{array}{c}\text { Beneficiários de programas sociais tendem a não querer trabalhar ("encostam no } \\
\text { Estado") }\end{array}$} \\
\hline & \multicolumn{2}{|c|}{$\begin{array}{l}\text { Discorda } \\
\text { Totalmente ou } \\
\text { em parte }\end{array}$} & \multicolumn{2}{|c|}{$\begin{array}{l}\text { Concorda } \\
\text { Totalmente ou } \\
\text { em parte }\end{array}$} & \multicolumn{2}{|c|}{$\begin{array}{c}\text { Não sabe } \\
\text { ou } \\
\text { não respondeu }\end{array}$} & \multicolumn{2}{|c|}{ TOTAL } \\
\hline & $\mathrm{N}$ & $\%$ & $\mathrm{~N}$ & $\%$ & $\mathrm{~N}$ & $\%$ & $\mathrm{~N}$ & $\%$ \\
\hline DEM & 1 & 33,3 & 2 & 67,7 & 0 & 0 & 3 & 100,0 \\
\hline PDT & 1 & 33,3 & 2 & 66,7 & 0 & 0 & 3 & 100,0 \\
\hline PMDB & 2 & 100,0 & 0 & 0 & 0 & 0 & 2 & 100,0 \\
\hline PP & 0 & 0 & 1 & 100,0 & 0 & 0 & 1 & 100,0 \\
\hline PPS & 0 & 0 & 2 & 100,0 & 0 & 0 & 2 & 100,0 \\
\hline PRP & 0 & 0 & 1 & 100,0 & 0 & 0 & 1 & 100,0 \\
\hline PSB & 1 & 33,3 & 2 & 66,7 & 0 & 0 & 3 & 100,0 \\
\hline PSC & 0 & 0 & 1 & 100,0 & 0 & 0 & 1 & 100,0 \\
\hline PSDB & 4 & 28,6 & 10 & 71,4 & 0 & 0 & 14 & 100,0 \\
\hline PSL & 0 & 0 & 1 & 100,0 & 0 & 0 & 1 & 100,0 \\
\hline PT & 2 & 66,7 & 1 & 33,3 & 0 & 0 & 3 & 100,0 \\
\hline PV & 0 & 0 & 0 & 0 & 1 & 100,0 & 1 & 100,0 \\
\hline TOTAL & 11 & 31,43 & 23 & 65,7 & 1 & 2,9 & 35 & 100,0 \\
\hline
\end{tabular}

Talvez estes dados reflitam uma concepção sobre políticas públicas que se afasta de abordagens que frisam a clivagem de classe e seus efeitos na segregação e na desigualdade social. Abordagens como a de Lojkine (1981), por exemplo, que articulam desigualdade social e políticas públicas que, no geral, beneficiam camadas de alta renda e, também, estudos como de Marques e Bichir (2001; 2002) sobre políticas públicas e configuração espacial que sustentam a relação entre ausência ou insuficiência de políticas públicas nos espaços e para a população de baixa renda e a dimensão da precariedade social em que vivem.

Para uma aproximação sobre quais seriam os valores dos vereadores de acordo com o perfil ideológico-partidário, trabalhou-se com as variáveis independentes partidos políticos e responsabilidade do Estado e a variável dependente programas sociais e desestímulo para o trabalho.

\section{Relação entre valores políticos sobre programas sociais e perfil ideológico-partidário}

Metade dos vereadores dos partidos de esquerda/centro-esquerda e $76,1 \%$ dos de direita/centro direita concordam que beneficiários de programas sociais tendem a não querer trabalhar; o maior número destes últimos é coerente com o perfil ideológico esperado em relação à sua filiação partidária (Tabela 11): 
OPINIÃO PÚBLICA, Campinas, vol. 18, n², novembro, 2012, p. 309-336

Tabela 11

Valores dos vereadores de de partidos de direita/centro-direita ou esquerda/centro-esquerda sobre programas sociais e trabalho Gestão 2009.2012

\begin{tabular}{|c|c|c|c|c|c|c|}
\hline \multirow{3}{*}{$\begin{array}{l}\text { Beneficiários de programas sociais } \\
\text { tendem a não querer trabalhar } \\
\text { ("encostam no Estado") }\end{array}$} & \multicolumn{6}{|c|}{ Partido } \\
\hline & \multicolumn{2}{|c|}{$\begin{array}{c}\text { Direita e } \\
\text { centro-direita }\end{array}$} & \multicolumn{2}{|c|}{$\begin{array}{c}\text { Esquerda e } \\
\text { centro-esquerda }\end{array}$} & \multicolumn{2}{|c|}{ Total } \\
\hline & Frequência & $\%$ & Frequência & $\%$ & Frequência & $\%$ \\
\hline Concorda Totalmente ou em parte & 16 & 76,1 & 7 & 50,0 & 23 & 65,7 \\
\hline Discorda Totalmente ou em parte & 5 & 23,8 & 6 & 42,9 & 11 & 31,4 \\
\hline Não sabe ou não respondeu & 0 & 0 & 1 & 7,1 & 1 & 2,9 \\
\hline Total & 21 & 100,0 & 14 & 100,0 & 35 & $\begin{array}{c}100 \\
0\end{array}$ \\
\hline
\end{tabular}

Obs. Colunas em destaque para a realização dos testes de independência Q de Yule e de correlação Q de Yule.

A dependência estatística entre as variáveis aponta que os vereadores dos partidos de direita/centro-direita tendem a concordar com a afirmação que beneficiários de programas sociais tendem a não querer trabalhar (delta 0,053). 0 teste indica uma correlação moderada $(0,466)$. Quer dizer, há $46,6 \%$ de chance a mais de encontrar vereadores de direita e centro-direita que concordam com esta afirmação ${ }^{31}$.

A força da correlação é maior quando a variável independente não é o perfil ideológico. partidário dos vereadores, mas a noção sobre responsabilidade do Estado. Metade dos vereadores que optam pela alternativa garantir o bem estar social e, também, 76,2\% que escolhem manter a ordem e respeitar as liberdades individuais concordam que programas sociais podem desestimular os beneficiários a trabalhar (Tabela 12). De novo, é menor a ambiguidade entre os vereadores mais conservadores e liberais.

Tabela 12

Concepções de vereadores de Curitiba sobre responsabilidade do Estado e sobre programas sociais Gestão 2009.2012

\begin{tabular}{|c|c|c|c|c|c|c|}
\hline $\begin{array}{c}\text { Beneficiários de programas sociais } \\
\text { tendem a não querer trabalhar } \\
\text { ("encostam no Estado") }\end{array}$ & \multicolumn{5}{|c|}{ Principal responsabilidade do Estado } \\
\cline { 2 - 7 } & $\begin{array}{c}\text { Garantir bem } \\
\text { estar social }\end{array}$ & $\begin{array}{c}\text { Manter a ordem ou } \\
\text { respeitar as } \\
\text { liberdades }\end{array}$ & \multicolumn{2}{|c|}{ Total } \\
\cline { 2 - 7 } & $\mathrm{N}$ & $\%$ & $\mathrm{~N}$ & $\%$ & $\mathrm{~N}$ & $\%$ \\
\hline Concorda Totalmente ou em parte & 6 & 50,0 & 16 & 76,2 & 22 & 62,97 \\
Discorda Totalmente ou em parte & 6 & 50,0 & 4 & 19,0 & 10 & 28,6 \\
Não sabe ou não respondeu & 0 & 0 & 1 & 4,8 & 1 & 2,7 \\
Total & 12 & 100,0 & 21 & 100,0 & $35^{*}$ & 100,0 \\
\hline
\end{tabular}

*Respostas anuladas: 2 Obs. Colunas em destaque para a realização dos testes de independência Q de Yule e de correlação Q de Yule ${ }^{32}$.

\footnotetext{
31 O resultado dos pares consistentes $(0,083)$ (vereadores de partidos de direita/centro-direita que concordam que programas sociais desestimulam para o trabalho e de partidos de esquerda/centro-esquerda que discordam) é mais forte que o resultado dos pares inconsistentes $(0,060)$ (vereadores de partidos de esquerda/centro-esquerda que concordam e de direita/centro-direita que discordam.

$32 \mathrm{Na}$ Tabela 12, há uma casa com valor menor que 5, no entanto, mantive os testes por entender que os resultados fornecem sugestões interessantes para a análise.
} 
KAUCHAKJE, S. Solidariedade e expressão jurídica: valores políticos de vereadores...

Há dependência estatística entre as variáveis. Os vereadores que consideram que a principal responsabilidade do Estado é manter a ordem ou respeitar as liberdades individuais tendem a concordar que beneficiários de programas sociais tendem a não querer trabalhar (delta 0,07) e há um número menor (do que o esperado, caso as variáveis fossem independentes) de vereadores que escolhem a alternativa garantir bem estar e, também, concordam com aquela afirmação sobre programas sociais (ver área sombreada da Tabela 4). A correlação é substancial, sendo que o teste de correlação Q de Yule indica que há $62 \%$ de chance a mais de encontrar vereadores que preferem as alternativas manter a ordem ou respeitar as liberdades individuais e que concordam que programas sociais podem representar um desestímulo para o trabalho ${ }^{33}$.

Em síntese, a maioria dos vereadores desconsiderou transferência de renda como um direito universal, discordou de sua inserção como direito na legislação, mas consentiu que programas de transferência de renda são necessários para atender carências sociais. A maioria também concordou que beneficiários de programas sociais tendem a não querer trabalhar. Há uma relação de dependência estatística entre estes valores e a filiação partidária e, também, entre as concepções sobre o Estado. 0 sentido da correlação é que vereadores de direita/centro-direita e que manifestam concepções conservadora e liberal sobre o Estado tendem a associar programas sociais com desestímulo ao trabalho, não obstante tais valores estejam presentes, também, entre os demais parlamentares.

Para compreender valores sobre programas sociais, a correlação com a variável concepções sobre responsabilidade do Estado é mais forte quando comparada com correlação com a variável filiação partidária. Como mencionado anteriormente, estes dados que lidam com o perfil ideológico-partidário dos vereadores fornecem elementos para discussão que, sob outro enfoque, estão presentes em autores como Lavalle, Houtzager e Castello (2006) e Power e Zucco (2009), isto é, em que medida partidos políticos são centrais na atualidade, especialmente, neste caso, para o ordenamento e modelação de valores de seus membros, bem como, se esquerda e direita ainda são referenciais com potencial preditivo.

Os resultados também sugerem que, para áreas recentemente incorporadas na legislação social, os valores da maioria dos parlamentares municipais de Curitiba são compatíveis com o tipo de solidariedade benevolente que admite ajuda e doação antes que direitos sociais.

\section{Valores sobre direitos sociais e expressão jurídica}

Os direitos sociais garantidos na CF88 são tidos como "expressões do princípio fundamental da solidariedade" (COMPARATO, 2001, p. 10). Em consonância com a tipologia de solidariedade elaborada, considero que a validação subjetiva desta norma expressa a solidariedade política.

\footnotetext{
33 O resultado dos pares consistentes $(0,188)$ (o par formado por: a) vereadores que optam pelas alternativas manter a ordem ou respeitar as liberdades individuais e que concordam com a afirmação segundo a qual beneficiários de programas sociais tendem a não querer trabalhar e; b) vereadores que escolhem garantir bem estar social e que discordam) é mais forte do que o resultado dos pares inconsistentes $(0,047)$ (o par formado por: c) vereadores que optam pela alternativa garantir bem estar social e que concordam e; d) vereadores que escolhem manter a ordem e liberdades que discordam da afirmação sobre programas sociais).
} 327 
OPINIÃO PÚBLICA, Campinas, vol. 18, no 2, novembro, 2012, p. 309-336

Na legislação social, os direitos à saúde, à previdência e à assistência social compõem o direito à seguridade social cujo artigo constitucional fixa a universalidade da cobertura e do atendimento e, também, a seletividade e distributividade na prestação dos benefícios e serviços, com caráter não contributivo para o caso da saúde e da assistência social e contributivo para a previdência social. A universalidade e o caráter não contributivo também caracterizam os direitos à educação.

Direitos e políticas universais agregam a priorização social, como é o caso da assistência social, da educação e da segurança alimentar e nutricional que, embora destinados a todos, preveem serviços e benefícios específicos para pessoas com deficiência, idosos e com baixa renda, por exemplo. A habitação social, por sua vez, é destinada a pessoas de baixa renda e prioriza famílias "chefiadas" por mulheres, com idosos e pessoas com deficiência. A legislação sobre o trabalho regula a jornada, condições de trabalho, remuneração e seguro-desemprego, entre outros aspectos das relações de trabalho. Os artigos constitucionais sobre estes direitos sociais também explicitam o dever do Estado e a participação complementar do setor privado ${ }^{34}$.

Em meados dos anos 1990, no interior da chamada reforma do Estado e da regulamentação dos artigos constitucionais (FAGNANI, 2005), os princípios da universalização dos direitos sociais e a prestação estatal dos serviços sociais foram contrapostos à orientação para políticas sociais focalizadas e para a oferta e prestações sociais em parceria com organizações da sociedade civil. Esta orientação tem rebatimentos atuais na implementação da política social e no debate sobre universalidade ou focalização.

Por um lado, Boito (2007) argumenta que programas sociais focalizados na população de baixa renda, ao invés das políticas sociais universais, acabam por incidir sobre a capacidade e qualidade de atendimento dos serviços previdenciários, de saúde e educação, por exemplo. Situação que impulsiona parte da classe média baixa e as classes com rendimento superiores a buscarem tais bens no mercado, fortalecendo, assim, um mercado de serviços sociais, às vezes, articulado com o setor financeiro nacional e internacional, como é o caso da previdência privada alojada nos bancos. Particularmente, a ênfase em políticas focalizadas de transferência renda está alinhada com o "discurso ideológico neoliberal que estigmatiza os direitos sociais como privilégios" (BolTo, 2005, p. 54).

Por outro lado, Neri $(2007,2011)$ verifica que nos anos 2000, políticas de transferência de renda e de educação provocaram a diminuição da desigualdade de renda, especialmente pelo aumento de renda nos estratos inferiores da pirâmide de renda.

Para Draibe (2003), em sociedades profundamente desiguais, a focalização (com distribuição de benefícios na proporção inversa das carências) pode "reduzir as chances da reprodução da desigualdade sob o manto de programas universais" (DRAIBE, 2003, p. 11). A "mescla virtuosa" entre programas universais, programas focalizados e, também, arranjos de priorização social no interior de políticas universais (recursos e serviços destas políticas destinados a grupos vulneráveis pela idade,

\footnotetext{
34 Lembro que as ONGs são entidades de direito privado, sem fins lucrativos, que realizam atividades de interesse público (SIMÕES, 2007). Portanto, mesmo consideradas um terceiro setor, são rigorosamente, incluídas no âmbito privado.
} 328 
KAUCHAKJE, S. Solidariedade e expressão jurídica: valores políticos de vereadores...

deficiência, pobreza e discriminação pelo gênero ou cor da pele, por exemplo) podem ter impacto redistributivo mais efetivo do que a eleição de uma das alternativas (DRAIBE, 2002, p. 8).

Dito de outro modo, um arranjo de política social que combina princípios de universalidade, priorização social e focalização parece ter potencial para diminuir desigualdades de renda e para o reconhecimento de diferenças e identidades, ou seja, pode cumprir o objetivo de modificar o padrão histórico que define cidadania como privilégio de classe.

A compatibilidade entre a legislação social nos tópicos sobre universalidade e dever do Estado . e os valores dos parlamentares municipais foi verificada a partir de questões sobre público-alvo e responsabilidade na implemantação de políticas sociais.

Em conformidade com a legislação social estão $97,1 \%$ dos vereadores que consideram a educação como política universal; $85,7 \%$ a saúde; $68,6 \%$ a segurança alimentar e nutricional e $51,4 \%$ a assistência social. Pouco mais da metade $(57,1 \%)$ dos parlamentares municipais entendem a transferência de renda como medida destinada aos setores de baixa renda, em consonância com a legislação brasileira sobre a renda mínima nas variações BPC e Bolsa Família; 40,0\%, deles, entretanto, estão alinhados ao caráter universal da transferência de renda em concordância com a lei 10.835/04 sobre renda de cidadania (Tabela 13):

Tabela 13

Público-alvo das políticas sociais segundo os vereadores de Curitiba Gestão 2009.12

\begin{tabular}{|l|c|c|c|c|c|c|}
\hline Público - alvo e setores da política socia & \multicolumn{2}{l|}{ Toda pop. } & \multicolumn{2}{l|}{$\begin{array}{l}\text { Grupos sociais } \\
\text { específicos }\end{array}$} & \multicolumn{2}{l|}{ Total } \\
\cline { 2 - 7 } & $\mathbf{N}$ & $\%$ & $\mathbf{N}$ & $\%$ & $\mathbf{N}$ & $\%$ \\
\hline Saúde & 30 & 85,7 & 5 & 14,3 & 35 & 100,0 \\
Educação & 34 & 97,1 & 1 & 2,9 & 35 & 100,0 \\
Assistência social & 18 & 51,4 & 17 & 48,6 & 35 & 100,0 \\
Previdência social & 27 & 77,1 & 8 & 22,9 & 35 & 100,0 \\
Habitação & 24 & 68,6 & 11 & 31,4 & 35 & 100,0 \\
Trabalho & 30 & 85,7 & 5 & 14,3 & 35 & 100,0 \\
Segurança alim. e nut. & 24 & 68,6 & 11 & 31,4 & 35 & 100,0 \\
Transferência de renda & 14 & 40,0 & 20 & 57,1 & $34 *$ & 97,1 \\
\hline *NS
\end{tabular}

A CF88 e a legislação social estabelecem a competência do Estado, provisão pública e complementaridade do setor privado na implementação de políticas sociais. Para todas as áreas dos diretos sociais, mais da metade dos vereadores foi coerente com as garantias legais e considerou que a responsabilidade em implementar políticas e programas sociais é do Estado, ou principalmente do Estado (Tabela 14). 
OPINIÃO PÚBLICA, Campinas, vol. 18, n², novembro, 2012, p. 309-336

Chama a atenção que, a despeito de 17 vereadores não identificarem transferência de renda como direito social e 23 deles não aceitarem sua inscrição na legislação, apenas 5 tinham considerado que a sociedade civil teria responsabilidade exclusiva por programas nesta área (Tabelas 7, 9 e 14). Isto denota a tendência dos vereadores em validarem a implementação de políticas governamentais nesta área com caráter de ajuda e não de garantia legal.

Tabela 14

Responsabilidade em implementar políticas e programas sociais segundo os vereadores de Curitiba . Gestão 2009-12

\begin{tabular}{|c|c|c|c|c|c|c|c|c|c|c|c|c|}
\hline \multirow{3}{*}{ Áreas } & \multicolumn{12}{|c|}{ Responsabilidade em implementar políticas e programas sociais } \\
\hline & \multicolumn{2}{|c|}{ Só Estado } & \multicolumn{2}{|c|}{$\begin{array}{c}\text { So soc. } \\
\text { civil }\end{array}$} & \multicolumn{2}{|c|}{$\begin{array}{l}\text { Ambos } \\
\text { Princ. } \\
\text { Estado }\end{array}$} & \multicolumn{2}{|c|}{$\begin{array}{l}\text { Ambos } \\
\text { Princ. } \\
\text { Soc. civil }\end{array}$} & \multicolumn{2}{|c|}{ NR } & \multicolumn{2}{|c|}{ Total } \\
\hline & $\mathbf{n}$ & $\%$ & $\mathrm{~N}$ & $\%$ & $n$ & $\%$ & $n$ & $\%$ & $\mathrm{~N}$ & $\%$ & $n$ & $\%$ \\
\hline Saúde & 10 & 28,6 & 0 & 0 & 23 & 65,7 & 1 & 2,9 & 1 & 2,9 & 35 & 100,0 \\
\hline Educação & 8 & 22,9 & 0 & 0 & 22 & 62,9 & 4 & 11,4 & 1 & 2,9 & 35 & 100,0 \\
\hline Assist. social & 7 & 20,0 & 0 & 0 & 22 & 62,9 & 4 & 11,4 & 2 & 5,7 & 35 & 100,0 \\
\hline Previd. social & 12 & 34,3 & 0 & 0 & 20 & 57,1 & 2 & 5,7 & 1 & 2,9 & 35 & 100,0 \\
\hline Habitação & 10 & 28,6 & 0 & 0 & 23 & 65,7 & 1 & 2,9 & 1 & 2,9 & 35 & 100,0 \\
\hline Trabalho & 5 & 14,3 & 0 & 0 & 20 & 57,1 & 9 & 25,7 & 1 & 2,9 & 35 & 100,0 \\
\hline Segurança alim & 11 & 31,4 & 0 & 0 & 19 & 54,3 & 4 & 11,4 & 1 & 2,9 & 35 & 100,0 \\
\hline Transf. de renda & 11 & 31,4 & 1 & 2,9 & 17 & 48,6 & 4 & 11,4 & 2 & 5,7 & 35 & 100,0 \\
\hline
\end{tabular}

Observando todas as áreas em conjunto, $80 \%$ dos entrevistados seguem a orientação constitucional sobre a responsabilidade do Estado (Tabela 15): 
KAUCHAKJE, S. Solidariedade e expressão jurídica: valores políticos de vereadores...

Tabela 15

Valores de vereadores de Curitiba por filiação partidária, sobre responsabilidade em implementar políticas e programas sociais

Gestão 2009-2012

\begin{tabular}{|c|c|c|c|c|c|c|c|c|c|c|}
\hline \multirow[t]{4}{*}{ Partidos } & \multicolumn{10}{|c|}{$\begin{array}{l}\text { Responsabilidade em implementar políticas e programas } \\
\text { sociais }\end{array}$} \\
\hline & \multicolumn{2}{|c|}{ Só Estado } & \multicolumn{2}{|c|}{ Só Soc. Civil } & \multicolumn{4}{|c|}{ Ambos } & \multicolumn{2}{|c|}{ TOTAL } \\
\hline & \multirow{2}{*}{$\mathbf{N}$} & \multirow{2}{*}{$\%$} & \multirow{2}{*}{$\mathrm{N}$} & \multirow{2}{*}{$\%$} & \multicolumn{2}{|c|}{$\begin{array}{l}\text { Princ. } \\
\text { Estado }\end{array}$} & \multicolumn{2}{|c|}{$\begin{array}{l}\text { Princ. } \\
\text { soc. civil }\end{array}$} & \multirow{2}{*}{$\mathrm{N}$} & \multirow{2}{*}{$\%$} \\
\hline & & & & & $\mathrm{N}$ & $\%$ & $\mathrm{~N}$ & $\%$ & & \\
\hline DEM & 0 & 0 & 0 & 0 & 3 & 100,0 & 0 & 0 & 3 & 100,0 \\
\hline PDT & 1 & 33 & 0 & 0 & 2 & 66,7 & 0 & & 3 & 100,0 \\
\hline PMDB & 0 & 0 & 0 & 0 & 2 & 100,0 & 0 & & 2 & 100,0 \\
\hline PP & 0 & 0 & 0 & 0 & 1 & 100,0 & 0 & & 1 & 100,0 \\
\hline PPS & 1 & 50 , & 0 & 0 & 1 & 50,0 & $\overline{0}$ & & 2 & 100,0 \\
\hline PRP & 0 & 0 & 0 & 0 & 1 & 100,0 & 0 & & 1 & 100,0 \\
\hline PSB & 0 & 0 & 0 & 0 & 3 & 100,0 & 0 & & 3 & 100,0 \\
\hline PSC & 0 & 0 & 0 & 0 & 1 & 100,0 & 0 & & 1 & 100,0 \\
\hline PSDB & $\overline{0}$ & $\overline{0}$ & $\overline{0}$ & $\overline{0}$ & 11 & 78,6 & 3 & & 14 & 100,0 \\
\hline PSL & 1 & 10 & 0 & 0 & 0 & 0 & 0 & & 1 & 100,0 \\
\hline PT & 1 & 33 , & 0 & 0 & 2 & 66,7 & 0 & & 3 & 100,0 \\
\hline $\mathrm{PV}$ & 0 & 0 & 0 & 0 & 1 & 100,0 & 0 & & 1 & 100,0 \\
\hline TOTAL & 2 & 5,7 & 0 & 0 & 28 & 80,0 & 3 & & 35 & 100,0 \\
\hline
\end{tabular}

Os dados da Tabela 15 mostram que a variável partido (direita/centro-direita; esquerda/centroesquerda) é independente da variável responsabilidade com políticas e programas sociais ${ }^{35}$.

Os resultados compatibilidade entre valores dos vereadores e a normas legais demonstraram que: a maior ou menor compatibilidade sobre universalidade e focalização depende da área do direito social, sendo mais compatível para educação e saúde e menos para assistência social e segurança alimentar e nutricional e; são compatíveis com os artigos constitucionais os valores da maioria dos parlamentares sobre responsabilidade do Estado em cada uma das áreas dos direitos sociais.

Estes pontos de congruência apontam para a solidariedade civil-pública, mas, em áreas específicas, como a transferência de renda ou assistência social, por exemplo, cabe a interpretação de que os valores tendem para as características da solidariedade benevolente.

Os dados sobre associativismo e atendimento social podem auxiliar esta interpretação: a quase totalidade dos vereadores tem as duas formas de engajamento com significados diferentes: $88,6 \%$ deles realizam atendimento social que denota prestação de serviços e ajuda e; 71,4\% participam de alguma associação (ONG, movimento social, associação de bairro, por exemplo) que, supostamente, significaria forma de participação sócio-política com adesão aos direitos (Tabela 16):

35 Desnecessário fazer o teste de independência, pois há 80,0\% dos casos em uma categoria. 
OPINIÃO PÚBLICA, Campinas, vol. 18, n², novembro, 2012, p. 309-336

Tabela 16

Associativismo e atendimento social realizado por vereadores de Curitiba gestão 2009.2012

\begin{tabular}{|l|c|c|c|c|c|c|}
\hline & \multicolumn{1}{|c|}{$\begin{array}{c}\text { Não realiza } \\
\text { atividade social ou } \\
\text { presta serviço } \\
\text { social }\end{array}$} & \multicolumn{2}{|c|}{$\begin{array}{c}\text { Realiza atividade } \\
\text { social ou presta } \\
\text { serviço social }\end{array}$} & \multicolumn{2}{|c|}{ Total } \\
\cline { 2 - 7 } & $\mathbf{n}$ & $\%$ & $\mathbf{n}$ & $\%$ & $\mathbf{n}$ & $\%$ \\
\hline $\begin{array}{l}\text { Participa de associações } \\
\text { ou similares }\end{array}$ & 4 & 16,0 & 21 & 84,0 & 25 & 100,0 \\
$\begin{array}{l}\text { Não participa de } \\
\text { associações ou similares } \\
\text { Total }\end{array}$ & 0 & 0 & 10 & 100,0 & 10 & 100,0 \\
\hline
\end{tabular}

Neste circuito de relações nas instituições políticas, associações da sociedade civil e com a população diretamente, os parlamentares municipais, provavelmente, não antagonizam, mas, acomodam condutas e valores caracterizados nos tipos da solidariedade política e da solidariedade da dádiva.

\section{Considerações finais}

Na Câmara Municipal de Curitiba, a maioria dos vereadores da gestão 2009.2012 tem perfil ideológico liberal e conservador. Isto foi aferido pela filiação partidária, mas, principalmente, por conta dos valores sobre hierarquia social, responsabilidade do Estado, bem como sobre uma das áreas dos direitos sociais destacada - a transferência de renda.

Ficou demonstrado que para compreender os valores dos vereadores sobre programas sociais, a variável que trata da responsabilidade do Estado (manter a ordem, respeitar as liberdades individuais ou garantir bem estar) é mais forte do que a variável filiação partidária. Este dado traz elementos para discussão teórica sobre a centralidade atual dos partidos políticos, especialmente para a modelação de valores e, também, se as supostas diferenças ideológicas se traduzem coerentemente nas ações de seus membros (Lavalle, Houtzager, Castello, 2006; CARreirão, 2006; Power \& Zucco (2009).

Verificou-se, também, que a compatibilidade entre os valores e a legislação sobre direitos sociais é mais clara quando se trata das áreas da saúde e da educação, as quais a maioria dos vereadores considera serem direitos de cidadania universais e deveres do Estado com complementaridade do setor privado. Estes aspectos de coerência com artigos constitucionais sobre direito sociais manifestam valores compatíveis com a solidariedade civil-pública. Os valores sobre programas sociais no geral e, individualmente, sobre transferência de renda, são mais distantes de princípios de cidadania e próximos da solidariedade benevolente.

Estes resultados esclareceram, principalmente, que os valores políticos dos vereadores sobre direitos sociais têm maior acento no direito ou na benesse a depender de cada área específica dos direitos, mas trouxeram também questionamentos para a continuidade de pesquisas sobre a possível 
KAUCHAKJE, S. Solidariedade e expressão jurídica: valores políticos de vereadores...

relação entre valores condizentes com a solidariedade benevolente e o estabelecimento de conexões eleitorais.

Portanto, os valores dos vereadores de Curitiba sobre os direitos sociais, em conjunto, têm elementos dos tipos amplos de solidariedade política e de solidariedade da dádiva. Esta ambiguidade pode ser interpretada pela inserção e socialização dos parlamentares municipais tanto nas organizações políticas quanto da sociedade civil, partilhando da cultura política brasileira e da subcultura da classe política. Isto é, valores caracterizados como solidariedade política, possivelmente, estão relacionados à inserção nas instituições políticas que proporciona a cognição sobre as regras do jogo e matérias sociais. Valores caracterizados como solidariedade da dádiva são coerentes com a cultura da dádiva no Brasil que, como a literatura atesta (LEAL, 1997; DINIZ, 1982; LOPEZ, 2004), tem um forte reforço nas relações políticas locais, na qual os parlamentares municipais são um dos atores centrais.

\section{Referências Bibliográficas}

ABREu, N. M. C. Direitos fundamentais na Constituição Federal de 1988. Anais do Conselho Nacional de Pesquisa e PósGraduação em Direito, 2007.

ALmOnd, G.; Verba, S. The civic culture: political attitudes and democracy in five nations. Califórnia: Sage Publications, 1989.

ARretChe, M. "Emergência e desenvolvimento do Welfare State: teorias explicativas". B/B, n³4, 1995.

Estado federativo e políticas sociais: determinantes da descentralização. São Paulo: Fapesp/Revan, 2000.

BANFIELD, E. The Moral Basis of a Backward Society. Nova York: Free Press, 1958.

Behring, E. R.; Boschettı, I. Política social: fundamentos e história. São Paulo: Cortez, 2007.

BobBıo, N. A Era dos direitos. Rio de Janeiro: Campus, 1992.

Direita e esquerda. Razões e significados de uma distinção política. São Paulo: UNESP, 1995.

Boıтo, A. "A burguesia no Governo Lula“. Crítica Marxista, Rio de Janeiro, Revan, n’21, p. 52-76, nov. 2005.

"Estado e burguesia no capitalismo neoliberal". Revista Sociologia e Política, 28, p. 57.74, jun. 2007.

BoschI, R. R. e DıNIZ, E. O corporativismo na construção do espaço público. In: BosCHI, R. R. (org.). Corporativismo e desigualdade: a construção do espaço público. Rio de Janeiro: Rio Fundo, 1991.

BouRdieu, P. Escritos de Educação. Petrópolis: Vozes, 1998.

BouRdieu, P. Meditações pascalinas. Rio de Janeiro: Bertrand Brasil, 2007.

BRAGA, M. S. S. O processo partidário-eleitoral brasileiro, padrões de competição política (1982-2002). São Paulo: Associação Editorial Humanitas/FAPESP, 2006.

CARreIRÃo, Y. S. "Ideologia e partidos políticos: um estudo sobre coligações em Santa Catarina”. Opinião Pública, Campinas, vol. 12, n 1 , maio 2006.

Carvalmo, J. M. "Mandonismo, Coronelismo, Clientelismo: Uma Discussão Conceitual". Dados, Rio de Janeiro, vol. 40, n², 1997. 
OPINIÃO PÚBLICA, Campinas, vol. 18, n², novembro, 2012, p. 309-336

Cidadania no Brasil: o longo caminho. Rio de Janeiro: Civilização Brasileira, 2001.

CASTEL, R. As metamorfoses da questão social: uma crônica do salário. Petrópolis: Vozes, 2001

CAstro, H. C. O. et al. "Percepções sobre o Programa Bolsa Família na sociedade brasileira". Opinião Pública, Campinas, vol. 15, n 2, nov. 2009.

CERVI, E. U. "Produção legislativa e conexão eleitoral na assembléia legislativa do estado do Paraná". Revista de Sociologia e Política. Curitiba, vol. 17, n³2, p. 159.177, fev. 2009

Chauí, M. Raízes Teológicas do Populismo no Brasil: Teocracia dos Dominantes, Messianismo dos Dominados. In: Dagnino, E. (org.). Anos 90. Política e Sociedade no Brasil. São Paulo: Brasiliense, 1994.

Codato, A. Como funciona o parlamento brasileiro? 2009. Disponível em:

<http://adrianocodato.blogspot.com/2009/12/como-funciona-o-parlamento-brasileiro.html>. Acesso em: 20 maio 2010.

Comparato, F. K. "O papel do juiz na efetivação dos direitos humanos". Revista do Tribunal Regional do Trabalho da $15^{a}$ Região, Campinas, São Paulo, n 14, 2001.

CostA, P. R. N. Democracia nos anos 50: burguesia comercial, corporativismo e parlamento. São Paulo: Hucitec, 1998.

CostA, S. "Democracia cosmopolita: déficits conceituais e equívocos políticos". Revista Brasileira de Ciências Sociais. São Paulo, vol. 18, n53, 2003.

DINIZ, E. Voto e máquina política: patronagem e clientelismo no Rio de Janeiro. Rio de Janeiro: Paz e Terra, 1982.

DINIZ, S. "Interações entre os poderes executivo e legislativo no processo decisório: avaliando sucesso e fracasso presidencial". Dados, vol.48, no. 2, p.333.369, jun. 2005

Doımo, A. M. A vez e a voz do popular. movimentos sociais e participação político no Brasil pós-70. Rio de Janeiro: Relume-Dumará: ANPOCS, 1995.

DRAIBE, S. "Há tendências e tendências: com que Estado de Bem Estar Social haveremos de conviver neste fim de século?' Cadernos de Pesquisa NEPP, Unicamp, n¹0, 1989.

1993a.

"Welfare State no Brasil: características e perspectivas". Caderno de Pesquisa NEPP. Unicamp, n08, p. $5 \cdot 46,1993 b$.

"Qualidade de vida e reformas de programas sociais: o Brasil no cenário latino-americano". Lua Nova, n³1,

"Uma nova institucionalidade das políticas sociais? Reflexões a propósito da experiência latino-americana recente de reformas e programas sociais". São Paulo em Perspectiva, vol.11, n4, out.dez., 1997.

Brasil: A Proteção social em tempos difíceis. Taller Inter-Regional Protección Social en una Era Insegura: Un Intercambio Sur-Sur sobre Políticas Sociales Alternativas en Respuesta a la Globalización, 2002, Santiago. Seminário Internacional Protección Social en una Era Insegura, 2002.

"A política social no período FHC e o sistema de proteção social". Tempo Social, vol. 15, n’ 2, 2003.

Downs, A. Uma teoria econômica da democracia. São Paulo: Edusp, 1999.

ESPING-Andersen, G. "As três economias políticas do "Welfare State". Lua Nova, São Paulo, n² 24, p. 85-116, 1991.

Fagnani, E. Política social no Brasil (1964-2002): entre a cidadania e a caridade. Tese (Doutorado em Economia) Universidade Estadual de Campinas, Campinas, 2005.

FIgUeIRedo, I. Políticas públicas e a realização dos direitos sociais. Porto Alegre: Sergio Antonio Fabris, 2006.

FIORI, J. L. "Estado do Bem-Estar Social: Padrões e Crises". Instituto de Estudos Avançados, 1997.

Hobsbawm, E. J. Ecos da Marse/hesa. São Paulo: Companhia das Letras, 1996. 
KAUCHAKJE, S. Solidariedade e expressão jurídica: valores políticos de vereadores...

Hugo, V. Os Miseráveis. São Paulo: Cosac \& Naify, 2002.

Koerner, A. "Ordem política e sujeito de direito no debate sobre direitos humanos". Lua Nova, n 57, 2002.

KRISCHKE, P. J. "Governo Lula: políticas de reconhecimento e de redistribuição". Cadernos de Pesquisa Interdisciplinar em Ciências Humanas, $n^{\circ}$ 47, out. 2003.

Lavalle, A. G. "Cidadania, igualdade e diferença”. Lua Nova, nº 59, 2003.

Lavalle, A. G.; Houtzager, P. P.; Castello, G. "Democracia, Pluralização da Representação e Sociedade Civil”. Lua Nova, 67, p. 49-103, 2006.

LAVILLE, J. L. "Do século 19 ao século 21: permanência e transformações da solidariedade em economia". Katálysis, Florianópolis, vol. 11, n 1, jun. 2008.

LEAL, V. N. Coronelismo, enxada e voto: o município e o regime representativo no Brasil. Rio de Janeiro: Nova Fronteira, 1997.

Lenhart, G.; Offe, C. Teoria do Estado e Política Social. Tentativas de explicação político-sociológica para as funções e os processos inovadores da política social In: OFFE, C. Problemas estruturais do Estado capitalista. Rio de Janeiro: Tempo Brasileiro, 1984.

LoJKINE, J. O Estado capitalista e a questão urbana. São Paulo: Martins Fontes. 1981.

LOPEZ, F. G. "A política cotidiana dos vereadores e as relações entre executivo e legislativo em âmbito municipal: o caso do município de Araruama”. Revista de Sociologia e Política, n²2, p. 153-177, jun. 2004

MARQUES, E. C.; BICHIR, R. "Estado e espaço urbano: revisitando criticamente as explicações correntes sobre as políticas urbanas". Revista de Sociologia e Política, n¹6, p. 9.28, 2001.

"Investimentos públicos, infra-estrutura urbana e produção da periferia em São Paulo". Espaço \& Debates, São Paulo, n 42, p. 9.30, 2002.

Marshall, T. H. Cidadania, Classe Social e Status. Rio de Janeiro: Zahar Editores, 1967.

MARX, K. O capital. Livro 1, vol. 1. Rio de Janeiro: Civilização Brasileira, 1980.

A questão judaica. In: Manuscritos Econômicos-filosóficos. Lisboa: Edições 70, 1989.

Mauss, M. Sociologia e Antropologia. São Paulo: Cosac \& Naify, 2003.

Medeiros, M.; Britto, T.; Soares, F. "Transferência de renda no Brasil“. Novos estudos - CEBRAP, São Paulo, n 79, nov.2007.

MEIRELLES, M. Ferramentas administrativas para identificar, observar e analisar problemas: organizações com foco no cliente. São Paulo: Arte \& Ciência, 2001.

Miguel, L. F.; MACHADO, C. "Um equilíbrio delicado: a dinâmica das coligações do PT em eleições municipais (2000 e 2004)". Dados, Rio de Janeiro, vol. 50, n 4, 2007.

Moısés, J. A. "Cidadania, confiança e instituições democráticas”. Lua Nova, n65, p. 71.94, 2005.

MotTA, L. E. "Direito, Estado e poder: Poulantzas e o seu confronto com Kelsen”. Sociologia e Política, vol.19, n 38, p. 7.25, fev. 2011.

NeRI, M. C. "Pobreza e políticas sociais na década da redução da desigualdade". Nueva Sociedad, p. 53·75, out. 2007. Desigualdade de Renda na Década. FGV/CPS, 2011

Offe, C. Partidos Políticos e nuevos movimientos sociales. Editorial Sistema - Coleccion Politeia, 1993.

OliveirA, H. M. J. "Cultura política e Assistência social: desafios à consolidação de uma singular política pública no âmbito da proteção social”. Revista Ser Social, Brasília, UnB, n 12, p. 9 - p. 36, jan/jun 2003. 
OPINIÃO PÚBLICA, Campinas, vol. 18, n², novembro, 2012, p. 309-336

Perissinotto, R. M. \& BRAUnert, M. B. "A direita, a esquerda e a democracia: os valores políticos dos parlamentares paranaenses (1995/2003)”. Revista Opinião Pública, vol. 12, n 1, 2006.

Perissinotto, R. M.; Codato, A. N.; Fuks, M.; Braga, S. S. (orgs.). Quem governa? Um estudo das elites políticas do Paraná. Curitiba: Editora da UFPR, 2007.

PIOVESAN, F.; VIEIRA, R. S. "Justiciabilidade dos direitos sociais e econômicos no Brasil: desafios e perspectivas". Revista IberoAmericana de Filosofia, Política y Humanidades, v. 8, n 15, p. 128-146, abril 2006.

Power, T. \& Zucco, C. "Estimating Ideology of Brazilian Legislative Parties, 1990-2005: A Research Communication". Latin American Research Review, 44(1), p. 219-246, 2009.

Putnam, R. Comunidade e democracia: a experiência da Itália moderna. Rio de Janeiro: Fundação Getúlio Vargas, 2000.

RAICHelIS, R. “Gestão pública e a questão social na grande cidade”. Lua Nova, São Paulo, n 69, 2006.

REIS, E. "Percepções da elite sobre e pobreza e desigualdade". Revista Brasileira de Ciências Sociais, n 42, p. 143-152, 2000.

RIBEIRO, E. A. "Bases da legitimidade democrática no Brasil: adesão a valores e avaliação de desempenho". Opinião Pública, vol. 13, nº 1, p.74.96, jun. 2007.

SAlES, T. "Raízes da desigualdade social na cultura política brasileira". Revista Brasileira de Ciências Sociais, n²5, p.26-37, 1994.

SCherer-WARREN, I. "Das mobilizações às redes de movimentos sociais". Sociedade e Estado, Brasília, vol. 21, n 1, abr.2006.

SıMÕES, C. Curso de Direito do Serviço Social. Biblioteca Básica de Serviço Social, vol. 3. São Paulo: Cortez, 2007.

SINGER, A. Direita e esquerda no eleitorado brasileiro. São Paulo: EDUSP, 2000.

SouZA, C. "Governos locais e gestão de políticas sociais universais". São Paulo em Perspectiva, São Paulo, vol. 18, n’ 2 , p. $27 \cdot 41,2004$.

SouzA, N. R. A política pública e o espaço democrático: o caso do Conselho de Direitos da Criança e do Adolescente de Curitiba (COMTIBA). In: $3^{\circ}$ Encontro Nacional da ABCP - Associação Brasileira de Ciência Política. Anais... Universidade Federal Fluminense, Niterói: 2002.

TelLes, V. S. Direitos Sociais: Afinal do que se trata? Belo Horizonte: UFMG, 2000.

Tomı, F. R. L. Competição eleitoral e coalizões legislativas estaduais: conexão entre as arenas eleitoral e parlamentar nos estados. ANPOCS, 2007.

VASCONCELOS, T. A. C. A economia solidária como uma estratégia de desenvolvimento territorial: alguns aspectos teóricos. Dissertação (mestrado) - Universidade Federal de Uberlândia, Programa de Pós-Graduação em EconomiaUberlândia, 2007.

VILLA, R. D. "Segurança internacional e normatividade: é o liberalismo o elo perdido dos critical securities studies?" Lua Nova, São Paulo, n 73, 2008.

Weber, M. Economia y sociedad. México: Fondo de Cultura Económico, 1984.

Samira Kauchakje ·skauchakje@gmail.com

Submetido à publicação em maio de 2011 . Versão final aprovada em novembro de 2011. 